DOI 10.18551/rjoas.2020-06.06

\title{
EFFECT OF CUSTOMIZATION AND SOCIAL BONDING ON CUSTOMER LOYALTY MEDIATED BY TRUST VARIABLES
}

\author{
Patwayati* \\ Faculty of Economics and Business, Halu Oleo University, Indonesia \\ Marsini \\ Master's Study Program of Management, Halu Oleo University, Indonesia \\ *E-mail: patwayati.feb@gmail.com
}

\begin{abstract}
This research was conducted with the aim of knowing and analyzing the effect of customization and social ties on customer loyalty mediated by the variable of trust. The population in this study is the customer at the South Sulawesi Branch Bank Punggaluku. The total customers of Bank Sultra Punggaluku Branch in 2017 are around 2000 customers. The sample method in this study was determined using the Accidential sampling method. So that the sample taken can be said to be representative, then in this study using the Slovin formula, the sample in this study was determined as many as 116 customers, with sample criteria, namely: 1 . Customers who are directly related to multipurpose loans, namely civil servants in southern Konawe, 2. Customers who have multipurpose credit facilities, 3. Customers who have experienced multipurpose loans for about 1 year. The analytical tool used is SEM. The research results obtained based on the results of the analysis are that: 1. Customization ties have a positive and significant effect on the trust of customers in multipurpose banking at South Sulawesi Branch of Punggaluku; 2. Social ties have a positive and significant effect on the trust of multipurpose credit customers at the South Sulawesi Bank Punggaluku Branch; 3 . The customization bond has a positive and significant effect on the loyalty of multipurpose loan customers at the South Sultra Bank, Punggaluku Branch; 4. Social ties have a positive and significant effect on the loyalty of multipurpose credit customers at the South Sulawesi Bank Branch, Punggaluku; 5. Trust has a positive and significant effect on the loyalty of multipurpose loan customers at the South Sulawesi Regional Bank Punggaluku Branch; 6. Customization ties have a positive and significant effect on customer loyalty through the trust of customers of multipurpose credit at Bank Sultra Punggaluku Branch; 7. Social ties have a positive and significant effect on customer loyalty through the trust of multipurpose credit customers at the South Sulawesi Bank Punggaluku Branch.
\end{abstract}

\section{KEY WORDS}

Ties of customization, social ties, trust, loyalty.

In an effort to improve its performance, Sultra Bank implements corporate culture (Organizational Behavior) as a core value (Core Values) which is a series, values and assumptions that are believed to exist and are shared in a company or work environment owned by individuals, employees, and work groups in the company. Bank Sultra's corporate culture is the main behavior that must be highlighted in daily activities for all company instruments. The culture is contained in TIPSS (Trust, Integrity, Professional, Synergy and Service Excellence).

Bank Sultra has a wide range of products. One of them is multipurpose loans, the development of the number of customers from multipurpose loans shows a general phenomenon that occurs in South Sulawesi Bank, namely the efforts made by the South Sulawesi South Sulawesi Branch Bank in building relationships with customers as reflected in TIPSS as a corporate culture have not fully been able to increase loyalty, seen of Behavioral and customer attitudes. This condition is seen from the relatively small 
development of the number of new multipurpose loan customers. This phenomenon raises the question of how the Punggaluku branch of the Southeast Sulawesi Bank can attract or obtain the maximum number of new customers who are interested in multipurpose credit facilities.

In daily operations Bank Sultra competes with other banks in various products. The existence of such competition causes customers to be unfaithful (not loyal), and can result in the loss of existing customers. Customer loyalty becomes very important for service providers; customer loyalty can be built and enhanced by establishing and maintaining relationships with customers. As stated by Berry (1983) in Alrubaiee (2008) which examines the relationship marketing relationship (Relationship Marketing) and loyalty, stating that Relationship marketing is a tool to achieve Customer Lolyalty. Furthermore Zithaml et al (1996) argue that the ultimate goal of a company's success in establishing relationships with relationships is to establish strong loyalty.

Studies on relationship marketing have been conducted by many researchers. Morgan and Hunt (1994) examined two key relationship marketing factors that must be considered by company management in building long-term relationships with customers. The two keys are trust and commitment. Both of these variables are stated as Key Mediating Variables in the relationship marketing model, and if the assessment of commitment and trust is carried out together and not just one at a time it can increase efficiency, effectiveness and productivity.

Another variable that is key in relationship marketing is trust. Hasanuddin (2007) interprets trust as a customer's trust in a company or brand because the customer believes that the company or brand is able to provide value beyond his expectations. The definition shows that the more capable the service provider or company is in growing confidence in the customer that the product of the company has a value that exceeds expectations, the more it will foster customer confidence in the product and company. The meaning of trust also shows the importance of conducting a study of customer trust.

The relationship between customer trust and loyalty has been done by several researchers. Research results from (Ahmadi and Fatehipoor 2013; Rai 2013; Zalarzehi and Rahmaninejat 2013) show that trust has a significant effect on customer loyalty which means that increasing or decreasing customer confidence in a product or company can cause an increase or decrease in customer loyalty.

The results of the study are also in line with the theory of trust put forward by Swan and Nolan (1985) in Hasanuddin (2007) that long-term customer loyalty will be realized if the customer has a high level of trust in the product or company. Thus without high trust, true loyalty will not be realized.

Social ties according to Smith (1998) show personal ties such as intimacy, friendship, and various experiences with customers and empathize with customers. The relationship of social ties with loyalty has theoretically been reviewed by Palmatier (2008: 42) based on the results of research conducted previous. Research conducted by Chiu et al (2007) showed that social ties significantly influence customer loyalty. This means that the increasing efforts by service providers or companies to bind customers with a social approach, then customer loyalty will increase significantly. The results of this study are in line with the results of research by (Palmatier et al, 2009; Djatmiko, 2013; Supriadi and Melanta, 2014) show that social ties significantly influence loyalty. However, research from (Farida, 2007); Nsour, 2013) shows different results where social ties do not significantly influence customer loyalty. Thus there are still gaps or gaps based on the results of research on the effect of social ties on customer loyalty.

The type of bond that is no less important for service providers or companies to engage customers to be loyal to the company is a customization bond. Shruthi and Devaraja (2012) interpret the customization ties as an effort made by the company to provide services in accordance with customer needs. Service delivery in this type of bonding is tailored to the needs of customers and is known as One to One Marketing (Mudie and Angela Pirrie 2006: 236), and can be done to encourage customer loyalty through in-depth knowledge of individual customers and through the development of special solutions tailored to specific needs of individual customers. 
Parasuraman, 1991; Supriadi and Melanta, 2014; Hasanuddin, 2009; Fisher, 2003: 37 incorporates customization ties in the component of Relationship Marketing Strategy. Palmatier (2008: 42) does not insist on customization ties in the Relationship Marketing program. Although there are differences of the two opinions, the customization bond is still included in the effort made by the service provider to grow a bond with the recipient of the service, or in other words it is still included in the concept of bonding. In the current marketing concept, the provision of services that are tailored to the individual needs of customers is very important because the demands and expectations of customers are increasing and varied.

The description increasingly shows the importance of studies regarding customization ties including in the banking context as an effort to increase trust, so that customer loyalty can increase. Therefore, the customization ties in this study serve as one of the studies in influencing customer loyalty. The relationship between customization ties and customer loyalty has been done by Basalingappa and Subhas (2009) which shows the significant influence of the customization bond on loyalty. The results of these studies differ from the results of research from Supriadi and Melanta (2014) which show that customization ties do not have a significant effect on customer loyalty. Thus there are still gaps in the results of research on the effect of the ties of customization with customer loyalty so that it can be an opportunity to do a study in this study.

Sultra Bank in achieving competitive advantage with other banks, Sultra Bank faces various obstacles / phenomena that are specific to the South Sultra bank. The Punggaluku Branch currently has a multi-purpose credential customer of approximately two thousand (2000) customers of a total of around six thousand (6000 employees) ) Employees in southern konawe, so that in recruiting customers to use multipurpose loans specifically intended for employees has not been maximized, this is because employees who sit in credit are only handled by one person who acts as an employee serving customers in the office and as staff outside field, so that giving attention, maintaining relationships and interactions between individuals to customers who want to take multipurpose credit is very limited.

Providing a better understanding in accordance with the wishes of consumers has not been done, providing products in accordance with consumer specifications is not focused anymore so that overall it is not usual to provide excellent / innovative service, for now Bank Sultra is only waiting for customers who come to apply for credit.

\section{LITERATURE REVIEW}

Customization ties when service providers succeed in providing services tailored by loyal customers (Wirtz et al, 2012: 376) according to Hasanuddin (2009: 7) customization ties build long-term relationships with customers through in-depth understanding of individual customers and offering solutions " One the One "in accordance with the needs of the individual. This definition further strengthens the statement of Mudie and Pirrie (2006: 236), that ties of customization are created when customizing services delivered to certain groups of customers: in other words, providers make services according to customer needs.

Financial ties that provide economic benefits such as providing reduced administrative costs and increasing savings interest will be able to build customer preferences, but this is easily copied by competitors. So the company or service provider must try to improve social relations by paying attention to customers by studying the needs and desires of customers individually. therefore Berry (1995) and Berry and Parasuraman (1991) place social ties at the second or middle level in relationship marketing efforts to secure customer loyalty. This social bond according to Zeithaml et al (2006) is derived from the interaction of service providers and customers.

The concept of business development today is focused on developing long-term customer loyalty to the company. One of the factors that influence long-term relationships in the form of customer loyalty is "Customer Trust". Without high customer trust in the company, customer loyalty will not be realized. Customers trust the company because promises made to customers are realistic or reliable, employees are honest and transparent in providing 
information and services that are needed by customers, the company has high competency that makes the company superior to competitors, and company staff have a friendly, polite, and like nature assist customers in completing complaints to the company. This is important because customers buy goods generally in the company that really can be trusted so that customers are guaranteed from the risk of fraud that causes customers to suffer losses.

Indicators of trust measurement according to Ndubisi and Wah (2005) are measured by three indicators, namely:

- Believe that Bank employees have competence;

- Trust the credibility of Bank employees;

- Trust the Bank to provide quality services.

Entering the new millennium, the orientation of the company's future experiences a shift from conventional approaches to contemporary approaches. The conventional approach emphasizes customer satisfaction, cost reduction, market share, and market research. While the contemporary approach focuses on Customer Loyalty, customer retention, zero defections, and customer lifelong. According to Schnaars (1998) there are four possible types of relationships between Customer Satisfaction and Customer Loyalty: failures, forced loyalty, defectors, and successes. Not only are loyal customers highly potential to become word-of-mouth advertisers, but they are also likely to be loyal to the company's portfolio of products and services for a long time. The term Customer Loyalty is actually a large part of brand loyalty which reflects Customer Loyalty to a particular brand and its use is not differentiated and can be used interchangeably.

Repurchase behavior is often associated with brand loyalty. However, there are differences between the two. If brand loyalty reflects a psychological commitment to a particular brand, then the repurchase behavior is simply the purchase of the same specific brand repeatedly (it can be the only available brand, the cheapest brand, and so on).

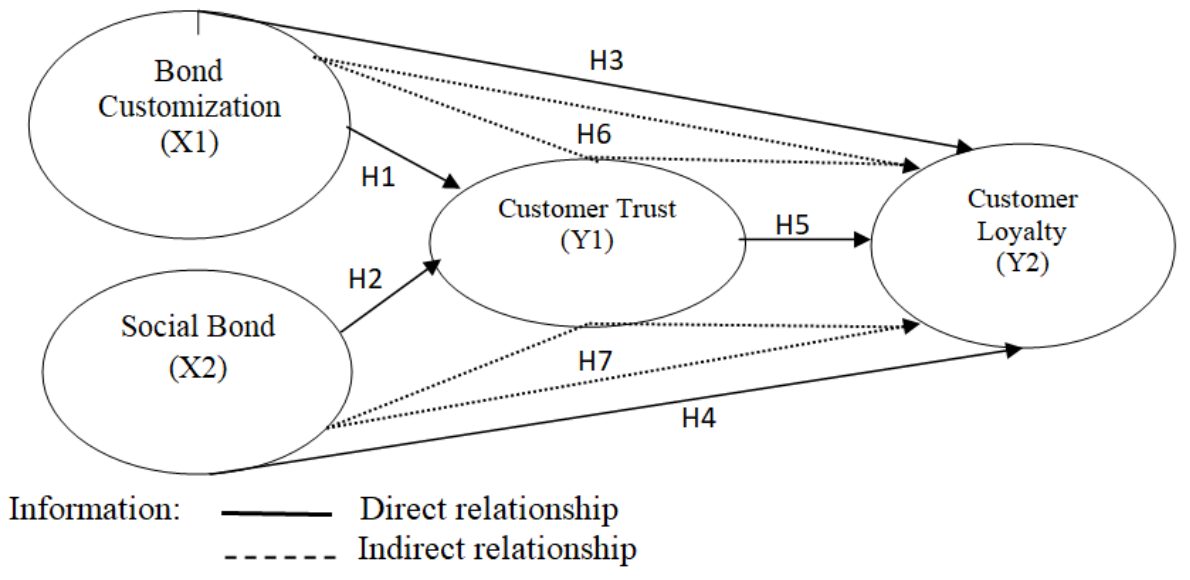

Figure 1 - Research Conceptual Framework

Based on the background and literature review that has been described, then the next is the preparation of hypotheses in this study. Hypotheses can be defined as logically estimated relationships between two or more variables expressed in the form of testable statements (Now, 2006):

$\mathrm{H} 1$ : The Customization Bond has a positive and significant effect on Customer's Trust;

H2: Social ties have a positive and significant effect on Customer Trust;

H3: The Customization Bond has a positive and significant effect on customer loyalty;

$\mathrm{H} 4$ : Social ties have a positive and significant effect on customer loyalty;

$\mathrm{H} 5$ : Trust has a positive and significant effect on customer loyalty

H6: Bond Customization has a positive and significant effect on customer loyalty mediated by trust variables;

$\mathrm{H7}$ : Social ties have a positive and significant effect on customer loyalty which is mediated by the variable of trust. 


\section{METHODS OF RESEARCH}

According to M. Naszir (2003: 271), states that, "the population is a collection of individuals with quality and characteristics that have been determined. Population in this study is the customer at the South Sulawesi Branch Bank Punggaluku. The total customers of Bank Sultra Punggaluku Branch in 2017 are around 2000 customers.

The sample is part of the total characteristics possessed by the population (Sugiyono 2011: 120). In this study, the sample method in this study was determined using the Accidential sampling method, which is a sampling technique based on chance meeting with anyone who is a customer, especially a multipurpose credit customer with a researcher, so that it can be used as a sample if it is deemed that the person is suitable as a source of data. So that the sample taken can be said to be representative, then in this study must determine the sample size by using the Slovin formula as follows:

$$
N=N 1+N(e) 2
$$

Based on the results of these calculations, the sample in this study was determined as many as 116 customers.

Data analysis methods used in this research are descriptive analysis and inferential statistics, namely Structural Equation Modeling (SEM) using AMOS (Analysis of Moment Structural) software, Microsoft Excel, and SPSS software.

\section{RESULTS OF STUDY}

Testing and empirical verification of the influence between variables of this study in addition to using descriptive statistical analysis also used inferential statistical analysis, namely Structural Equation Modeling (SEM) with the hope that a synthesis process will occur in order to perfect the findings. The data used are data collected from 116 respondents who are multipurpose credit customers of the South Sulawesi Bank Branch Punggaluku. So that the sample size of this study required by Hair et., AI (2006) is 100-200 to meet the provisions of the structural equation model. In addition the minimum sample size is 5 observations for each estimated parameter and a maximum of 10 observations for each estimated parameter.



Figure 2 - Output Path Diagram

The application of Structural Equation Modeling (SEM) analysis in this study was carried out in several stages, namely: assumption test, measurement model test through confirmatory factor analysis, structural model feasibility analysis, structural relationship model 
analysis and hypothesis testing built in the study. Next estimate the loading value of each indicator variable and the influence between variables of this study was carried out with the help of Analysis of Moment Structural (AMOS) software.

The feasibility testing phase of the model consists of two stages of testing, namely testing the measurement model and structural capital. Goodness of fit testing is carried out to determine the size of the model fit with the research data obtained. The image is the path diagram that is produced after conducting the SEM assumption test discovery stage. The path diagram is shown in the Figure 2.

Table 1 - Analysis of Goodness of Fit

\begin{tabular}{|c|c|c|c|}
\hline Goodness Of Fit Index & Cut-off Value & Values on Research Models & \multirow{2}{*}{ Information } \\
\hline Chi-Square $\left(\mathrm{X}_{2}\right)$ & The smaller the better & 445,813 & Good fit \\
\hline $\mathrm{p}$ (Probability) & $<0,05$ & 0,000 & Poor fit \\
\hline CMIN/DF & $<2,0$ & 75,00 & Good fit \\
\hline GFI & $>0,90$ & 0,463 & Good fit \\
\hline AGFI & $>0,90$ & 0,500 & Good fit \\
\hline TLI & $>0,90$ & 0,819 & Good fit \\
\hline CFI & $>0,90$ & 0,851 & Poor fit \\
\hline RMSEA & $<0,08$ & 0,214 & \\
\hline
\end{tabular}

Source: Data Processed, 2019.

Table 1 shows the GOF test results which concluded that the model is fit with the research data but the loading factor $>0.50$ can be used to make GOF test results better. Indicators of the research variables used in this study have a loading factor value that shows a very complex relationship between variables that are accurately predicted based on the coefficient of the relationship between construct, significance level and R-square value, following by presenting the model criteria and values critically.

Structural relationship model test is done after the structural model built in this research is in accordance with the observational data and the suitability index of the structural relationship model to determine the relationship between fellow latent variables designed in this study. The latent variables constructed in this research consisted of: customization ties $(\mathrm{X} 1)$, social ties (X2), trust $(\mathrm{Y} 1)$, and customer loyalty (Y2). The latent variables of customization ties are measured by three indicator variables, in the initial test of this study; they showed that the three indicator variables are valid and reliable to explain the observational data. The results of the final model measurement analysis with confirmatory factor analysis show that the three indicators forming the latent variable of the customization bond have a factor loading value that is still above the cut-point number, thus indicating that the correlation between all positive variables and the factors formed.

Latent variables of social ties are measured by three items indicator variables, from the three indicators of measurement of social ties variables are valid and reliable to explain the observational data and have a loading factor of each indicator variable is still above the limiting number (cut of point) so it indicates that the correlation all positive variables with the factors formed are latent variables of social ties.

The latent variable of trust is measured through three indicator variables and the three indicators are valid and reliable to explain the observational data and have a factor loading value of each indicator variable is still above the limiting number (cut of point) so it indicates that the correlation of all positive variables with factors formed is the latent variable of trust.

Then the latent variable of customer loyalty is measured through four indicator variables and the four indicators are valid and reliable to explain the observational data and have a factor loading value of each indicator variable is still above the limiting number (cut of point) so it indicates that the correlation of all variables is positive with the factors formed are latent variables of customer loyalty.

Furthermore, the four latent variables in this research are linked to produce five direct relationships and one indirect relationship in this research model. five direct relationships in the structural model referred to in this research, namely: (1) the ties of customization to trust; 
(2) social ties to trust; (3) customization ties to customer loyalty; (4) social ties to customer loyalty; (5) trust in customer loyalty; and (6) customization ties and social ties influence customer loyalty which is mediated by the variable trust of credit customers at the South Sultra Bank Punggaluku Branch.

The results of the analysis of the suitability of the structural model were built as a basis for analyzing the relationships between latent variables and testing hypotheses first presented standardized regression weights in order to find out the relationship between the latent variables hypothesized and the significance level of causality in the Table 2.

Table 2 - Standardized Regression Weights Between Latent Research Variables

\begin{tabular}{|c|c|c|c|c|c|c|}
\hline No & \multicolumn{2}{|l|}{ Direct influence } & Path coefficient & (t-value) & Prob. & Information \\
\hline 1. & $\begin{array}{l}\text { Bond Customization } \\
(\mathrm{X} 1)\end{array}$ & Trust (Y1) & 0,310 & 7,040 & 0,000 & Significant \\
\hline 2. & Social ties (X2) & Trust (Y1) & 0,675 & 3,776 & 0,005 & Significant \\
\hline 3. & Customization (X1) & Customer Loyalty (Y2) & 0,841 & 2,755 & 0,001 & Significant \\
\hline 4. & Social ties (X2) & Customer Loyalty (Y2) & 0,112 & 6,825 & 0,007 & Significant \\
\hline 5. & Trust (Y1) & Customer Loyalty (Y2) & 0,703 & 5,019 & 0,000 & Significant \\
\hline \multicolumn{7}{|c|}{ Indirect effects (Standardized Indirect Effects) } \\
\hline No & Variable Exogenous & Intervening Variable & Variable Endogenous & \multicolumn{2}{|c|}{ Indirect Effects } & Information \\
\hline 1. & $\begin{array}{l}\text { Bond customization } \\
(\mathrm{X} 1)\end{array}$ & $\begin{array}{l}\text { Trust } \\
(\mathrm{Y} 1)\end{array}$ & $\begin{array}{l}\text { Customer loyalty } \\
\text { (Y2) }\end{array}$ & \multicolumn{2}{|l|}{ ty 0,000} & Significant \\
\hline 2. & Social ties (X2 & $\begin{array}{l}\text { Trust } \\
\text { (Y1) }\end{array}$ & $\begin{array}{l}\text { Customer loyalty } \\
(\mathrm{Y} 2)\end{array}$ & \multicolumn{2}{|l|}{$\left.y\right|_{0,008}$} & Significant \\
\hline
\end{tabular}

Source: Primary Data Processed with AMOS Version 20 Software.

The results of the standardized regression weights estimation, critical ratio or t test and probability in table 2 show that there are five direct relationship models built in this research, all of which are: (1) customization ties have a positive and significant effect on trust; (2) social ties have a positive and significant effect on trust; (3) customization ties have a positive and significant effect on customer loyalty; (4) social ties have a positive and significant effect on customer loyalty; and (5) Trust has a positive and significant effect on customer loyalty. The results of this analysis prove that customer loyalty is largely determined by the ties of customization and social ties in the South Sultra Bank Punggaluku Branch. Customization ties have a significant effect on customer loyalty through trust that can be seen in the indirect effect of 0,217. Furthermore, social ties have a significant effect on customer loyalty through trust that can be seen in the indirect effect of 0,474 . Trust functions as a variable between connecting and strengthen the influence of customization and social ties on customer loyalty.

\section{DISCUSSION OF RESULTS}

Standardized regression coefficient weight estimate (factor loading) between customization ties to customer trust Multipurpose Loans at South Sulawesi Regional Bank Punggaluku 0.310 with a probability value $(P)$ of $0,000<\alpha=0.05$ which is the level of significance determined by researchers in this research. This test proves that customization ties have a positive and significant effect on the trust of multipurpose lending customers at Bank Sultra Punggaluku Branch. The better the employee's customization ties to customers, the better the trust of multipurpose credit customers at Bank Sultra Punggaluku Branch. Changes in the direction of customization ties in a direct and significant way to increasing trust. Thus, the first hypothesis proposed in this research proved to be acceptable.

Standardized regression coefficient weight estimate (factor loading) between social ties to customer trust Multipurpose Loans South Sulawesi Branch Punggaluku 0, 675 with a probability value $(P)$ of $0.005<\alpha=0,05$ which is the level of significance determined by researchers in this research. This test proves that social ties have a positive and significant effect on the trust of multipurpose loan customers at the South Sulawesi Regional Bank Punggaluku Branch. The better the social ties of employees to customers, the better the trust 
of multipurpose credit customers at the South Sulawesi Bank Punggaluku Branch. Changes in social ties in the same direction and significant to increasing trust. Thus, the second hypothesis proposed in this research proved to be acceptable.

Standardized regression coefficient weight estimate (factor loading) between customization ties to customer loyalty Multipurpose Loans Bank Sultra Branch Punggaluku0, 841 with a probability value $(P)$ of $0.001<\alpha=0.05$ which is the level of significance determined by researchers in this research. This test proves that the customization ties have a positive and significant effect on the loyalty of multipurpose lending customers at Bank Sultra Punggaluku Branch. The better the employee's customization ties to customers, the better the loyalty of multipurpose credit customers at Bank Sultra, Punggaluku Branch. Changes in the direction of customization ties in a direct and significant way to increase customer loyalty. Thus, the third hypothesis proposed in this research proved to be acceptable.

Standardized regression coefficient weight estimate (factor loading) between social ties to customer loyalty Multipurpose Loans, South Sulawesi Regional Bank Punggaluku 0.112 with a probability value $(P)$ of $0.007<\alpha=0,05$ which is the level of significance determined by researchers in this research. This test proves that social ties have a positive and significant effect on the loyalty of multipurpose loan customers at the South Sulawesi Regional Bank Punggaluku Branch. The better the social ties of employees to customers, the better the loyalty of multipurpose credit customers, Bank Sultra, Punggaluku Branch. Changes in direct and significant social ties to increase loyalty. Thus, the fourth hypothesis proposed in this research proved to be acceptable

Standardized regression coefficient weight estimate (factor loading) between trust in customer loyalty Multipurpose Loans South Sulawesi Regional Bank Punggaluku 0, 703 with a probability value $(P)$ of $0,000<\alpha=0,05$ which is the level of significance determined by researchers in this research. This test proves that trust has a positive and significant effect on the loyalty of multipurpose loan customers at the South Sulawesi Regional Bank Punggaluku Branch. The better employee confidence in customers, the better the loyalty of multipurpose credit customers at the South Sulawesi Bank Punggaluku Branch. Changes in trust are unidirectional and significant to increasing customer loyalty. Thus, the fifth hypothesis proposed in this research proved to be acceptable.

The effect of the customization bond variable on customer loyalty mediated by trust is the multiplication between the path coefficient of the direct influence of the customization bond variable on trust and the path coefficient of the direct effect of customization bond on customer loyalty. In order to get the path coefficient value of the indirect effect of the customization bond variable on customer loyalty through the trust of the multipurpose credit customers of the South Sulawesi Bank branch of Punggaluk in the amount of 0.217. Because the path coefficient value of the influence of the customization bond variable on customer loyalty through significant trust, it can be concluded directly that the increase in real or significant customization bonds can increase customer loyalty through higher trust. Indirect relationship patterns (mediation), customization bond variables, and trust directly to customer loyalty, both have a significant effect, but testing the direct effect between customization bond variables on customer loyalty is significant. Thus the role of trust mediation can be regarded as a complete mediation variable (complete mediation)

The effect of social bond variable on customer loyalty mediated by trust is the multiplication between the direct effect coefficient path coefficients of social bond variable on trust with the path coefficient of direct influence social bond on customer loyalty. In order to obtain the path coefficient value of the indirect effect of social ties variable on customer loyalty through the trust of customers of multipurpose credit Bank Punggalukus branch of 0.474 . Because the path coefficient value of the influence of social bond variables on customer loyalty through significant trust, it can be concluded directly an increase in real or significant social ties can increase customer loyalty through higher trust. The pattern of indirect relationships (mediation), social bond variables, and trust directly on customer loyalty, both have a significant effect, but testing the direct effect between social bond 
variables on customer loyalty is significant. Thus the role of trust mediation can be regarded as a complete mediation variable (complete mediation).

Research Limitations. This study has several limitations that cannot be generalized to all banks in Southeast Sulawesi in particular and generally in Indonesia. The limitations referred to are: 1. this study cannot be generalized to all customers of PT. Bank Sultra in Southeast Sulawesi, because respondents taken in this study are of different characters, 2. Respondents in this study do not differentiate from customers who have savings in other banks.

\section{CONCLUSION}

Based on the results of research and discussion, it can be concluded as follows: 1 . Customization ties have positive and significant influence on the trust of customers in multipurpose banking in South Sulawesi, Punggaluku Branch, 2. Social ties have a positive and significant effect on the trust of multipurpose customers in Bank Sultra, in Branch Punggaluku, 3. Customization ties have a positive and significant effect on the loyalty of multipurpose lending customers at Bank Sultra in Punggaluku Branch, 4. Social ties have a positive and significant effect on the loyalty of multipurpose lending customers. 6 . Customization ties have a positive and significant effect on customer loyalty through the trust of customers in multipurpose credit at Bank Sultra Punggaluku Branch, 7. Social ties have a positive and significant effect on customer loyalty through customer trust. Multipurpose credit at the South Sultra Bank Punggaluku Branch.

Based on the above conclusions, it can be suggested a number of things to be carried out as follows: 1. The results of the variable description based on the respondents' perception of the South Sulawesi Branch of Punggaluku indicator organizing activities to establish intimacy with customers having the lowest average value. Thus the policy makers and leaders at PT. Bank Sultra punggaluku branch is more focused attention on these indicators, by increasing the ability of employees of PT. Bank Sultra punggaluku branch in giving attention to customers, increasing comfortable operating hours for all customers and employees needs to increase understanding of specific customer needs. 2. Respondents' perceptions of the service loyalty variable in the indicator recommends multipurpose loans have the lowest mean value is this shows that the management at PT. Bank Sultra punggaluku branch has not provided excellent service to its customers. Causing a lack of customer confidence in the South Sulawesi Branch Bank Punggaluku.

\section{REFERENCES}

1. Adu (2012). The use and management of ict in schools: strategies for school Leaders.European Journal of Computer Science and Information Technology (EJCSIT). Vo.

2. Al-Nsour, Marwan (2012). Relationship between Incentives and Organizational Performance for Employees in the Jordanian Universities. International Journal of Business and Management. 7, 78-89

3. Alrubaiee, L (2008). 'Investigate the Impact of Relatonship Marketing. Orientation on Customer Loyalty: The Customer's Perspective'. International. Journal of Marketing.

4. Astuti, Dewi (2001). Manajemen Keuangan Perusahaan. Jakarta: Ghalia Indonesia.

5. Barnes, James G (2003). Secrets Of Customer Relationship Management,

6. Berry, L. Leonard and Parasuraman A (1991). A Marketing services. New york: The Free Press

7. Berry, Leonard L (1995). Relationship Marketing of Service: Growing Interest,. Emerging Perspectives, Journal of the Academy of Marketing Science,. 23 (fall), 246-51.

8. Begalle (2008). Study showed that not every dimension of RM had significant influence. Equity and.... influence of RM towards customer satisfaction for example

9. Bua, Hasanuddin (2007). Pengaruh Kompetensi Agen Terhadap Loyalitas Nasabah. Melalui Kepercayaan Nasabah Pada Agen and Kepercayaan Nasabah. 
10. Dewani, sinha (2013). Analisis Faktor-Faktor Yang Mempengaruhi Struktur Modal (Studi Perbandingan Pada Perusahaan Aneka Industri and Consumer Goods Periode 20072009).

11. Juharsah (2011). Peranan Rasa Syukur, Kepercayaan, and Komitmen Dalam Memediasi Pengaruh Ikatan Finansial, Ikatan Sosial, Ikatan Kustomisasi, and Ikatan Struktural Terhadap Loyalitas.

12. Keiningham et al, (2007). Meningkatkan loyalitas pelanggan telah menjadi topic hangat di kalangan manajer, konsultan, and akademisi.

13. Kotler, Philip (2000). Manajemen Pemasaran, Edisi Milenium, Jakarta.

14. Lin, et al (2006). The Effect of Ausit Committee Performance on Earnings Quality. Mangerial Auditing Journal, 21.

15. Elsevier Ltd. Simamora, Bilson (2004). Panduan Riset Perilaku Konsumen. Gramedia Pustaka. Utama.

16. Mudie, peter and Pirrie, Angela (2006). Service Marketing Managemen Thirdedition. Routledge.

17. Morgan, M. R. \& Hunt, D. S (1994). The Commitment-Trust Theory Of Relationship. Marketing. The ournal of Marketing. Vol. 58 (July1994), hal. 20-38.

18. Morgan, R. and Hunt, S (1994). The Commitment-Trust Theory of The Relationship Marketing.

19. Nasir, M (2003). Metode Penelitian. Cetakan V. Jakarta

20. Ndubisi, Nelson Oly, \& Chan Kok Wah (2005). Factorial and Discriminant. Analyses of The Underpinnings of Relationship Marketing and Customer. Satisfaction. International Jurnal of Bank Marketing, Vol23.

21. Nolan, J (1985), "Gaining Customer Trust: A Conceptual Guide for.

22. Palmatier, W., Robert (2008), Relationship Marketing, Cambridge: Marketing Science Institute.

23. Paparoidamis, N. G. and Caceres, R. C (2005), Service Quality, Relationship.

24. Patwayati 2014 pengaruh kualitas layanan terhadap kepuasan, kepercayaan, komitmen and loyalitas pasien rawat inap pada rumah sakit umum provinsi sulawesi tenggara.

25. Peltier, James W. and John Westfall (2000), Dissecting the HMO-Benefits Managers Relationship: What to Measure and Why,ll Marketing Health Service, 20(2), 4-13.

26. Ruyter, Pascal Peeters, 1998, Investigating Drivers of Bank. Loyalty: The Complex Relationship between Images, Service Quality, and. Satisfactionll.

27. Sofyan Effendi, 1995, Metode Penelitian Survei, Edisi. Revisi, PT. PustakaLP3ES, Jakarta.

28. Solimun (2002). Multivariate Analysis Structural Equation Modelling (SEM) Lisrel dan. Amos. Fakultas MIPA.

29. Sugiyono. 2002. Metode Penelitian Administrasi. Bandung: CV Alfabet.

30. Schnaars, S.P (1998). Marketing Strategy: A Customer Driven Approach. Shammout et al (2007). Relational Bonds and Loyalty: The. Bonds that Tie. Kuantitatif Ikatan hubungan berpengaruh secara simultan terhadap loyalitas

31. Shammout , A.B. 2007. Evaluating an Extended Relationship Marketing Model or Arab Guests of Five-Star Hotels. Degree of Doctor of philosophy. Schoot of Hospitalilty, Tourism and Faculty of Business Marketing and low Victoria University Melbourne.

32. Subhash C. Jain (2007), Essentials of Global Marketing. South-Western College Publishing, USA.

33. Shruti. 2012. - Relationship between Work Environment And. Productivityll. IJERA, Vol. 2, Issue 4, July-August 2012.

34. Supriyadi, Winda Melanta (2014)Customer Relationship Management and Loyalitas Konsumen Pada PT Shafira Laras Persada.

35. Smith, T. M (1998). The my thof green marketing: Tending our goats at the edge of apocalypse. Toronto: University of Toronto Press.

36. Swastha (1998).Perilaku Konsumen Edisi Keenam, Jakarta.

37. Tjiptono, Fandy. 2007. Strategi Pemasaran. Edisi Kedua. Yogyakarta: Andi.

38. Swan, J.E., Nolan, J (1985), "Gaining Customer Trust: A Conceptual Guide for. 
39. Sri, Handayani (2010) pengaruh kepercayaan and komitmen terhadap loyalitas nasabah pada pt. bank negara indonesia (persero) tbk cabang padang.

40. Sri Wahyuni (2015) Pengaruh Relationship Quality terhadap Loyalitas Nasabah pada PT. Bank CIMBNIAGA Tbk Medan.

41. Tjiptono, Fandy. 2007. Strategi Pemasaran. Edisi Kedua. Yogyakarta: Andi.

42. Umar, Husein. 2002. Metode Riset Bisnis. Edisi Pertama. Jakarta: PT. Gramedia. Pustaka Utama.

43. Umar Sekaran, 2006, Metodologi Penelitian untuk Bisnis, Edisi 4, Buku 1, Jakarta: Salemba Empat.

44. Zeithaml et al., 1996. Measuring the quality of relationship in customer service: An empirical study, European. Journal of Marketing. 